\title{
The influence of food consumption and socio-economic factors on the relationship between zinc and iron intake and status in a healthy population
}

\author{
Marija Knez ${ }^{1,2, *}$, Marina Nikolic ${ }^{2}$, Milica Zekovic ${ }^{2}$, James CR Stangoulis ${ }^{1}$, \\ Mirjana Gurinovic ${ }^{2}$ and Maria Glibetic ${ }^{2}$ \\ 'School of Biological Sciences, Flinders University, Sturt Road, Bedford Park, Adelaide, SA 5042, Australia: \\ ${ }^{2}$ Centre of Research Excellence in Nutrition and Metabolism, Institute for Medical Research, University of Belgrade, \\ Belgrade, Serbia
}

Submitted 13 January 2017: Final revision received 26 April 2017: Accepted 16 May 2017: First published online 23 June 2017

\begin{abstract}
Objective: To examine $\mathrm{Zn}$ and Fe nutritional status of a healthy population by means of anthropometric, dietary and biochemical measurements and to investigate the relationship of usual $\mathrm{Zn}$ and Fe dietary intakes to $\mathrm{Zn}$ and Fe status. In addition, to examine the impact of food choices and socio-economic factors on Fe and $\mathrm{Zn}$ dietary intakes and status with the aim to identify groups at risk of dietary deficiency and suggest factors that may influence the status of these nutrients.

Design: Food consumption was assessed by $24 \mathrm{~h}$ recall questionnaires. Twenty biochemical parameters were measured, of which $\mathrm{Hb}$, haematocrit, erythrocyte count and plasma concentrations of Fe and $\mathrm{Zn}$ were directly related to Fe and $\mathrm{Zn}$ nutrition. The prevalence of study participants with inadequate micronutrient intakes was calculated using the Estimated Average Requirement cut-point method.

Setting: Serbia, Europe.

Subjects: Apparently healthy adults (25-65 years of age).

Results: Mean daily Zn and Fe intakes were $9.1 \mathrm{mg}$ and $11.6 \mathrm{mg}$ for males and $7.3 \mathrm{mg}$ and $9.4 \mathrm{mg}$ for females, respectively. Five per cent of the study population had inadequate dietary $\mathrm{Fe}$ intake and $15-25 \%$ had inadequate $\mathrm{Zn}$ intake. Lower $\mathrm{Hb}$ concentrations were measured in women with lower $\mathrm{Zn}$ intakes. No differences in Fe and $\mathrm{Zn}$ intakes and status among various socio-economic groups were observed, except for Fe intake between the low-income and affluent groups.

Conclusions: Regular follow-ups are needed to ensure that potential deficiencies of $\mathrm{Zn}$ and $\mathrm{Fe}$ do get recognized and addressed in a timely manner.
\end{abstract}

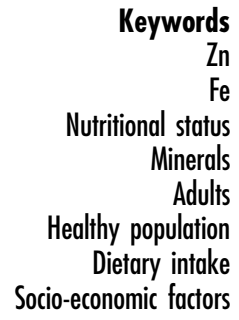

$\mathrm{Zn}$ and $\mathrm{Fe}$ are essential micronutrients for human health and are involved in many complex enzyme systems that function in various biological processes ${ }^{(1-3)}$. Deficiencies of these two nutrients remain a global problem, with the worldwide prevalence of Fe deficiency estimated to be about $30 \%{ }^{(4)}$ while approximately $20 \%$ of the world's population is affected by $\mathrm{Zn}$ deficiency ${ }^{(5)}$.

Although severe $\mathrm{Zn}$ deficiency is uncommon in developed countries, marginal deficiency is likely to be much more prevalent ${ }^{(6)}$ and is associated with certain functional outcomes; for instance, delayed wound healing, disturbances of taste and smell acuity, decreased work capacity and diminished immunological response ${ }^{(6-8)}$.

The burden of $\mathrm{Fe}$ and $\mathrm{Zn}$ deficiencies is most common in low-income countries; however, inadequate intake of these micronutrients is also seen in resource-rich areas of the world where overeating becomes a public health concern. Recent results from nutritional surveys conducted in the USA, Great Britain and Germany indicated that the recommended intakes of $\mathrm{Fe}$ and $\mathrm{Zn}$ are not always achieved $^{(9,10)}$. The population-based data from Europe suggested substantial variability in micronutrient intakes among healthy adults ${ }^{(9,10)}$. Data from the National Health and Nutrition Examination Survey 2001-2002 showed that $12 \%$ of the US population had $\mathrm{Zn}$ intake below the Estimated Average Requirement (EAR) ${ }^{(11)}$. Similarly, 10-35\% of Canadians from most age and sex groups consumed $\mathrm{Zn}$ in inadequate amounts ${ }^{(12)}$. Between 11 and $21 \%$ of the population from Greece, the UK and Finland had Fe intake below the $\mathrm{EAR}^{(13-15)}$. Similarly, a high percentage (39\%) 
of the population in the USA was also found to be at risk of inadequate $\mathrm{Fe}$ intake ${ }^{(16)}$. Women aged $14-50$ years are at particular risk of low Fe intake, as confirmed recently by results obtained from six European countries ${ }^{(10)}$. The prevalence of inadequate intakes of $\mathrm{Fe}$ and $\mathrm{Zn}$ is not consistent between studies performed in different developed countries. For Serbia in particular, the relevant data for adults are either old or scarce, therefore requesting additional investigation.

$\mathrm{Zn}$ is found in similar food sources to Fe, so insufficient dietary $\mathrm{Fe}$ and $\mathrm{Zn}$ intakes usually occur simultaneously ${ }^{(17,18)}$. Considering these diet-based similarities, there is a possibility that $\mathrm{Fe}$ and $\mathrm{Zn}$ status are also positively correlated. $\mathrm{Zn}$ metabolism interacts with the metabolism of $\mathrm{Fe}^{(19-21)}$. Similarly, it was noted that $\mathrm{Zn}$ and $\mathrm{Fe}$ nutriture are affected by many of the same dietary factors (i.e. Ca, phytate and polyphenols) ${ }^{(22,23)}$. The simultaneous occurrence of $\mathrm{Zn}$ and $\mathrm{Fe}$ deficiencies in man has been known since the discovery of Zn deficiency. Zn deficiency associated with Fe-deficiency anaemia was first recorded by Prasad et $a l^{(24,25)}$.

A number of studies over the years have demonstrated that $\mathrm{Zn}$ intake is correlated with $\mathrm{Hb}$ concentration ${ }^{(26,27)}$. However, it is not established if suboptimal $\mathrm{Zn}$ intake or slightly lower Zn status infers low Fe intake per se or low Fe status. Therefore, our objective was to identify relationships between $\mathrm{Zn}$ and Fe intakes and status in an apparently healthy population, where only marginal $\mathrm{Fe}$ and $\mathrm{Zn}$ deficiencies may occur.

The influence of socio-economic and demographic factors on $\mathrm{Zn}$ and $\mathrm{Fe}$ nutriture has been investigated to some degree ${ }^{(28,29)}$. However, information on the influence of educational level, marital and socio-economic position on mineral status in healthy populations is scarce, especially for $\mathrm{Zn}$ intake.

The current cross-sectional study reports on the current nutritional intakes of $\mathrm{Zn}$ and $\mathrm{Fe}$ in apparently healthy adults (25-65 years of age) living in Serbia and examines the relationship between dietary $\mathrm{Zn}$ and $\mathrm{Fe}$ intakes and related biochemical parameters. In addition, the study investigates the impact of food choices and socioeconomic factors on $\mathrm{Fe}$ and $\mathrm{Zn}$ dietary intakes and status with an aim to identify groups at risk of dietary deficiency and to suggest factors that may influence the status of these nutrients.

\section{Materials and methods}

\section{Study participants}

The study participants ( $n$ 754) were apparently healthy 25-65-year-old male and female volunteers recruited within an 18-month period from June 2013 to January 2015 through two different projects: National project III 41030 and the BACCHUS project (EU 7th Framework Programme (FP7), project no. 312090). The study participants were recruited through primary health-care facilities (community pharmacies and health centres) where flyers about participation in the study were distributed. Eligible subjects included apparently healthy people living in Serbia (as indicated by brief questionnaires, measure of blood pressure and blood glucose). Subjects without any clinical signs of an acute condition or chronic disease and without the need for medical treatment were included in the study. Pregnant and lactating women were excluded. All subjects went through the informed consent process, both verbal and written. The study protocols were approved by the Clinical Hospital Centre Zemun, Belgrade, Serbia (ethics committee approval number: 2125, 2013) and by the Southern Adelaide Clinical Human Research Ethics Committee (SAC HREC EC00188 approval number: 96.15), Adelaide, South Australia.

The protocols and procedures were in agreement with the ethical guidelines on biomedical research on human subjects of The Code of Ethics of the World Medical Association's Declaration of Helsinki (1964) and its further amendments.

\section{Assessment of dietary zinc and iron intakes}

Dietary intake data were collected for three nonconsecutive days, two working days and one weekend day, using the $24 \mathrm{~h}$ recall technique. All interviews were done face to face and led by a trained professional according to a standardized protocol. The estimated time of data collection was 15-30 min. During the interview, a food atlas with coloured photographs of 125 items (foods and composite dishes), illustrating a range of portion sizes in increasing order, was used in order to enhance the accuracy of portion size estimation ${ }^{(30)}$. In addition, to enhance interpretation of dietary estimates, general questions related to education, previous medical conditions, detailed food supplements, medication use, and lifestyle habits regarding smoking, physical activity/exercise, alcohol as well as coffee and tea consumption were also incorporated in the questionnaire. All questionnaires were checked for errors/ omissions together with study participants.

The $\mathrm{Zn}$ and Fe contents of foods were determined using the Serbian food composition database, harmonized with EuroFIR standards and embedded in the EuroFIR food platform and Balkan food platform ${ }^{(30,31)}$. DIETS ASSESS \& PLAN, a nutritional tool validated in different national and regional surveys and international projects, and evaluated in the European Food Safety Authority project, was used to obtain comprehensive dietary intake assessments ${ }^{(32)}$. Dietary data were entered in duplicate to ensure accuracy of data entry and to identify potential inconsistencies. Both the dietary intake assessment software used and the food composition data management system have integrated quality control mechanisms including mandatory fields, standard templates and error warnings ${ }^{(30,31)}$.

The dietary intakes from administered questionnaires were calculated by multiplying the frequency of consumption of 
each food item by the composition of that food using adequate portion sizes. In addition to $\mathrm{Zn}$ and Fe dietary intakes, data were obtained for energy, macronutrients and main food groups.

$\mathrm{Zn}$ and Fe contents of participants' diets were verified using the EAR, as defined in the Dietary Reference Intakes provided by the Institute of Medicine ${ }^{(33)}$. To check for under-reporting, the ratio of reported energy intake to predicted BMR was used, where BMR was estimated according to the Schofield equations ${ }^{(34)}$ taking into account age, sex and body weight.

\section{Collection of blood samples, socio-economic data and anthropometric measurements}

Blood samples were collected from a random sub-sample of 177 participants ( $23 \%$ of the study population) between 08.00 and 09.00 hours after an overnight fast $(>10 \mathrm{~h}$ fasting). Whole-blood samples were collected from participants in a seated position into trace-mineral-free tubes by venepuncture from an antecubital vein using butterfly needles (Sarstedt, Inc.). All samples were centrifuged ( $1000 \mathrm{~g}$ for $15 \mathrm{~min}$ ). The serum and plasma samples were removed and $1 \mathrm{ml}$ aliquots were stored at $-80^{\circ} \mathrm{C}$ until further analysis.

Data on the socio-economic and demographic characteristics of participants were collected via questionnaires. The risk of poverty was defined as 'the share of people with an equalised disposable income (after social transfer) below the at-risk-of-poverty threshold, which is set at $60 \%$ of the national median equalized disposable income ${ }^{,(35,36)}$.

Anthropometric variables, height and weight, were measured to the nearest $0 \cdot 1 \mathrm{~cm}$ and $0 \cdot 1 \mathrm{~kg}$, respectively. Body weight and body composition (muscle mass and fat tissue mass) of participants were measured using a TANITA UM072 balance (TANITA Health Equipment H.K. Ltd). BMI was computed as the ratio of weight to height squared $\left(\mathrm{kg} / \mathrm{m}^{2}\right)$. BMI was used to assess the prevalence of overweight $\left(25.0-29.9 \mathrm{~kg} / \mathrm{m}^{2}\right)$ and obesity $\left(\geq 30.0 \mathrm{~kg} / \mathrm{m}^{2}\right)$ according to WHO criteria ${ }^{(37)}$.

\section{Biochemical analysis}

The biochemical parameters were measured using a Cobas e411 clinical chemistry analyser (Roche Diagnostics) and using Roche Diagnostics kits according to the manufacturer's instructions.

Plasma $\mathrm{Fe}, \mathrm{Hb}$, haematocrit and erythrocyte count were used as markers of Fe status and plasma $\mathrm{Zn}$ was used for Zn status. Individuals were considered to be at risk of Fedeficiency anaemia if they had below-normal values for $\mathrm{Hb}(<120 \mathrm{~g} / \mathrm{l})$.

\section{Determination of plasma zinc and iron concentrations}

The assessment of Fe and $\mathrm{Zn}$ mineral status was performed for eighty-two participants (approximately $10 \%$ of the study population). The analysis of plasma $\mathrm{Zn}$ and $\mathrm{Fe}$ was conducted at the Institute of Public Health, Pozarevac, Serbia, using flame atomic absorption spectrometry on a Varian SpectrAA-10 instrument with instrument parameters: wavelength $213.9 \mathrm{~nm}$, slit width $1.0 \mathrm{~nm}$ and air-acetylene flame, according to the method described by Jian Xin ${ }^{(38)}$.

The concentrations of $\mathrm{Zn}$ and Fe were measured after dilution 1:10 with high-purity Milli-Q water ( $>18 \mathrm{M} \Omega$ resistivity). To verify the accuracy of the method for $\mathrm{Zn}$, control serum ClinChek-Control (Recipe, Chemical+ Instruments $\mathrm{GmbH}$; catalogue number 8880) with $\mathrm{Zn}$ concentration of 889 (SD 178) $\mu \mathrm{g} / \mathrm{l}$ (Level I) and 1738 (SD 261) $\mu \mathrm{g} / \mathrm{l}$ (Level II) was analysed. Likewise, for Fe, control serum ClinChek-Control (Recipe, Chemical + Instruments GmbH; catalogue number 8882) with Fe content of 612 (SD 122) $\mu \mathrm{g} / \mathrm{l}$ (Level I) and 1538 (SD 154) $\mu \mathrm{g} / \mathrm{l}$ (Level II) was used. Method performances were monitored by analysis of the same control serum within each series. The mean results for Zn concentration were 914 (SD 23) $\mu \mathrm{g} / \mathrm{l}$ (Level I) and 1801 (sD 35) $\mu \mathrm{g} / \mathrm{l}$ (Level II) which is in accordance with the certified values. In order to avoid $\mathrm{Zn}$ contamination, all tubes and utensils were either soaked in $\mathrm{HNO}_{3}(25 \%, \mathrm{w} / \mathrm{w})$ for $16 \mathrm{~h}$, or were known from previous studies to be $\mathrm{Zn}$-free. The mean results obtained for $\mathrm{Fe}$ content were 598 (sD 24) $\mu \mathrm{g} / \mathrm{l}$ (Level I) and 1529 (SD 55) $\mu \mathrm{g} / \mathrm{l}$ (Level II) which was in agreement with the certified values.

\section{Statistical analysis}

The distribution of data was tested using the ShapiroWilk's test for normality. Non-parametric statistical methods were applied for data that were not normally distributed.

The associations of $\mathrm{Zn}$ and Fe intakes and status with biochemical parameters were established by Spearman rank correlation. The effect of demographic and socioeconomic factors on $\mathrm{Fe}$ and $\mathrm{Zn}$ intakes and status was analysed using the Kruskal-Wallis test for factors that were divided in more than two categories and the Wilcoxon test for independent samples (Wilcoxon rank-sum test) for factors with two categories. Data are presented as means and SD and results are considered significant at $P<0 \cdot 05$. All analyses were performed using the R software package ${ }^{(39)}$.

\section{Results}

\section{Macronutrient, iron and zinc intakes of study participants}

The study sample included 754 participants, 128 males (17\%) and 626 (83\%) females. Table 1 shows mean intakes of macronutrients, Fe and $\mathrm{Zn}$ together with their percentage contributions to total energy intake.

Energy, protein and mineral crude intakes were significantly higher in men than in women $(P=0 \cdot 001)$. Under-reporting of food consumption was estimated to occur in $34 \%(260 / 754)$ of our study participants. The mean dietary $\mathrm{Zn}$ intake was $9.1 \mathrm{mg} / \mathrm{d}$ for males and 
Table 1 Macronutrient, iron and zinc intakes of apparently healthy Serbian adults, June 2013-January 2015

\begin{tabular}{|c|c|c|c|c|c|c|c|c|}
\hline & \multicolumn{4}{|c|}{ Males (25-65 years, $n$ 128) } & \multicolumn{4}{|c|}{ Females (25-65 years, $n$ 626) } \\
\hline & Mean & SD & $\%$ TE & SD & Mean & SD & $\%$ TE & SD \\
\hline \multicolumn{9}{|l|}{ Macronutrients } \\
\hline Energy $(\mathrm{kJ} / \mathrm{d})$ & 8937 & 3055 & - & - & 7135 & 1802 & - & - \\
\hline Energy (kcal/d) & $2135 \cdot 9$ & $730 \cdot 1$ & - & - & $1705 \cdot 3$ & $430 \cdot 7$ & - & - \\
\hline Protein $(\mathrm{g} / \mathrm{d})$ & 83.4 & $26 \cdot 0$ & 16.5 & 4.2 & $64 \cdot 3$ & $17 \cdot 7$ & $15 \cdot 7$ & 3.5 \\
\hline Total carbohydrate $(\mathrm{g} / \mathrm{d})$ & $207 \cdot 7$ & $99 \cdot 0$ & 39.1 & $10 \cdot 1$ & 183.5 & 55.4 & 44.5 & 7.5 \\
\hline Total fat $(\mathrm{g} / \mathrm{d})$ & 94.8 & $36 \cdot 6$ & 40.9 & 8.4 & 69.6 & $24 \cdot 3$ & 37.4 & $7 \cdot 1$ \\
\hline \multicolumn{9}{|l|}{ Minerals } \\
\hline $\mathrm{Zn}(\mathrm{mg} / \mathrm{d})$ & $9 \cdot 1$ & 4.6 & - & - & $7 \cdot 3$ & 3.8 & - & - \\
\hline & & & & & \multicolumn{2}{|c|}{$\begin{array}{c}\text { Females } \\
(<50 \text { years, } n 501)\end{array}$} & \multicolumn{2}{|c|}{$\begin{array}{c}\text { Females } \\
(\geq 50 \text { years, } n 125)\end{array}$} \\
\hline $\mathrm{Fe}(\mathrm{mg} / \mathrm{d})$ & $11 \cdot 6$ & $5 \cdot 4$ & & & $9 \cdot 4$ & 4.0 & $10 \cdot 0$ & 5.7 \\
\hline
\end{tabular}

$\% \mathrm{TE}$, percentage of total energy intake.

Table 2 Percentage of apparently healthy Serbian adults with iron intake below recommendations, June 2013-January 2015

\begin{tabular}{|c|c|c|c|c|c|c|}
\hline & \multicolumn{2}{|c|}{ Males (25-65 years, $n 128)$} & \multicolumn{2}{|c|}{ Females ( $<50$ years, $n 501)$} & \multicolumn{2}{|c|}{ Females $(\geq 50$ years, $n 125)$} \\
\hline & $\mathrm{Fe}$ RNI (mg/d) & \% below RNI & $\mathrm{Fe}$ RNI (mg/d) & $\%$ below RNI & $\mathrm{Fe}$ RNI (mg/d) & \% below RNI \\
\hline $\mathrm{FAO} / \mathrm{WHO}^{(53)}$ & $9 \cdot 1$ & $39 \cdot 8$ & $19 \cdot 6$ & $97 \cdot 8$ & 7.5 & $32 \cdot 8$ \\
\hline $\mathrm{IOM}^{(33)}$ & 8 & 23.4 & 18 & 96.6 & 8 & 36.7 \\
\hline IOM $(E A R)^{(33)}$ & 6 & 7.0 & $8 \cdot 1$ & 38.3 & 5 & 11.8 \\
\hline $\mathrm{NNR}^{(52)}$ & 9 & 35.9 & 15 & 94.6 & 9 & 50.0 \\
\hline
\end{tabular}

RNI, Recommended Nutrient Intake (the daily intake that meets the nutrient requirements of almost all (97.5\%) apparently healthy individuals in an age- and sex-specific population group); IOM, Institute of Medicine; EAR, Estimated Average Requirement (the daily intake that meets the nutrient needs of $50 \%$ of the healthy individuals in a specific population's group); NNR, Nordic Nutrition Recommendations.

$7.3 \mathrm{mg} / \mathrm{d}$ for females, while mean dietary Fe intake was $11.6 \mathrm{mg} / \mathrm{d}$ for males and $9.4 \mathrm{mg} / \mathrm{d}$ for females. $\mathrm{Zn}$ intake correlated with energy $(r=0.45)$, protein $(r=0.64)$, carbohydrate $(r=0.32)$ and $\mathrm{Fe}(r=0.57)$ intakes (all $P<0 \cdot 001)$.

Energy, protein, carbohydrate, Fe and $\mathrm{Zn}$ intakes were adequate according to the Dietary References Intakes for age and sex of the adult population ${ }^{(40)}$. However, the percentage of energy coming from fat was higher than the recommended amount: 40.9 and $37.4 \%$ of energy for males and females, respectively, compared with the recommended $20-35 \%{ }^{(40)}$.

\section{Percentage of population with iron and zinc intakes below dietary recommendations}

The percentage of the study population with low $\mathrm{Zn}$ intake was greater than the percentage with low Fe intake. After taking under-reporting into account, we estimated that $5 \%$ of the study population was at risk of inadequate $\mathrm{Fe}$ intake and 15-25\% was at risk of inadequate $\mathrm{Zn}$ intake. Females were at much higher risk of inadequate $\mathrm{Fe}$ intake, while males were at higher risk of inadequate $\mathrm{Zn}$ intake. Females below 50 years of age were at the highest risk of inadequate $\mathrm{Fe}$ intake. There were significant differences in the level of inadequacy observed when using dietary recommendations proposed by different expert groups (Tables 2 and 3).

\section{Anthropometric, socio-economic and biochemical data of study participants}

Main anthropometric and demographic characteristics of the study participants are presented in Tables 4 and 5 .

Anthropometric parameters measured in the present study fell within the reference ranges for the healthy adult population. The mean BMI of our study population was $26.8 \mathrm{~kg} / \mathrm{m}^{2}$ for males and $24.0 \mathrm{~kg} / \mathrm{m}^{2}$ for females. About $30 \%$ of males and $70 \%$ of female participants in our study (Table 4) had BMI values in the normal range ( $n$ 476), while about $30 \%$ of participants were overweight ( $n$ 277) and $10 \%$ were obese.

An assessment of marital status and education showed that $50 \%$ of participants were married and $34 \%$ were tertiary educated (Table 5).

Of the 754 participants included in the study, biochemical data were obtained for $23 \%$ of our study population (Table 5). Different biochemical and haematological parameters were assessed (twenty different indicators) with only parameters related to Fe status being presented (Table 5).

\section{Dietary intakes of zinc and iron of study participants}

Different food groups in relation to iron and zinc intakes Grains (mainly wheat, rye and rice) were the most important source of dietary Fe. The proportion of total dietary Fe coming from grains was about $30 \%$ for both genders. 
Table 3 Percentage of apparently healthy Serbian adults with zinc intake below recommendations, June 2013-January 2015

\begin{tabular}{|c|c|c|c|c|}
\hline & \multicolumn{2}{|c|}{$\begin{array}{c}\text { Males } \\
(25-65 \text { years, } n \text { 128) }\end{array}$} & \multicolumn{2}{|c|}{$\begin{array}{c}\text { Females } \\
(25-65 \text { years, } n \text { 626) }\end{array}$} \\
\hline & $\begin{array}{c}\text { Zn RNI } \\
(\mathrm{mg} / \mathrm{d})\end{array}$ & \% below RNI & $\begin{array}{c}\mathrm{Zn} \mathrm{RNI} \\
(\mathrm{mg} / \mathrm{d})\end{array}$ & $\%$ below RNI \\
\hline $\mathrm{FAO} / \mathrm{WHO}^{(53)}$ & 4.2 & $10 \cdot 2$ & 3 & 3.7 \\
\hline $\mathrm{IOM}^{(33)}$ & 11 & 73.4 & 8 & 69.4 \\
\hline IOM (EAR) $)^{(33)}$ & 9.4 & 60.2 & $6 \cdot 8$ & $50 \cdot 6$ \\
\hline $\mathrm{FAO} / \mathrm{WHO}^{(53)}$ & 9 & $58 \cdot 6$ & 7 & 53.8 \\
\hline IZiNCG $^{(92)}$ & 10 & $66 \cdot 4$ & 6 & 38.9 \\
\hline
\end{tabular}

RNI, Recommended Nutrient Intake (the daily intake that meets the nutrient requirements of almost all $(97.5 \%)$ apparently healthy individuals in an ageand sex-specific population group); IOM, Institute of Medicine; EAR, Estimated Average Requirement (the daily intake that meets the nutrient needs of $50 \%$ of the healthy individuals in a specific population's group); NNR, Nordic Nutrition Recommendations; IZiNCG, International Zinc Nutrition Consultative Group.

Table 4 Anthropometric measurements of apparently healthy Serbian adults, June 2013-January 2015

\begin{tabular}{|c|c|c|}
\hline & $\begin{array}{c}\text { Males } \\
(n 128)\end{array}$ & $\begin{array}{c}\text { Females } \\
(n 626)\end{array}$ \\
\hline Mean weight (kg) & 88.9 & 68.0 \\
\hline $\mathrm{SD}$ & 14.0 & 11.8 \\
\hline Mean height $(\mathrm{cm})$ & $181 \cdot 8$ & $168 \cdot 4$ \\
\hline SD & 0.1 & 0.1 \\
\hline Mean BMI $\left(\mathrm{kg} / \mathrm{m}^{2}\right)$ & $26 \cdot 8$ & $24 \cdot 0$ \\
\hline SD & 3.5 & $4 \cdot 0$ \\
\hline Mean WC $(\mathrm{cm})$ & 95.4 & 78.5 \\
\hline SD & $16 \cdot 9$ & $14 \cdot 3$ \\
\hline \multicolumn{3}{|l|}{ Nutritional status (by BMI; \%) } \\
\hline Underweight $\left(<18.5 \mathrm{~kg} / \mathrm{m}^{2}\right)$ & 0.8 & $2 \cdot 1$ \\
\hline Normal range $\left(18.5-24.9 \mathrm{~kg} / \mathrm{m}^{2}\right)$ & 30.5 & $69 \cdot 2$ \\
\hline Overweight $\left(\geq 25.0 \mathrm{~kg} / \mathrm{m}^{2}\right)$ & $68 \cdot 8$ & 28.8 \\
\hline Pre-obese $\left(25 \cdot 0-29.9 \mathrm{~kg} / \mathrm{m}^{2}\right)$ & $50 \cdot 8$ & $20 \cdot 0$ \\
\hline Obese class $1\left(30 \cdot 0-34.9 \mathrm{~kg} / \mathrm{m}^{2}\right)$ & $18 \cdot 0$ & 6.5 \\
\hline Obese class $2\left(35 \cdot 0-39.9 \mathrm{~kg} / \mathrm{m}^{2}\right)$ & 0.0 & 1.8 \\
\hline Obese class $3\left(\geq 40.0 \mathrm{~kg} / \mathrm{m}^{2}\right)$ & 0.0 & 0.5 \\
\hline \multicolumn{3}{|l|}{ Obesity co-morbidity risk (by WC; \%) } \\
\hline Level 1 (females $>80 \mathrm{~cm}$; males $>94 \mathrm{~cm}$ ) & $57 \cdot 0$ & $32 \cdot 9$ \\
\hline Level 2 (females $>88 \mathrm{~cm}$; males $>102 \mathrm{~cm}$ ) & $32 \cdot 0$ & $19 \cdot 0$ \\
\hline
\end{tabular}

WC, waist circumference.

Other important sources of Fe were meats (17\%) and vegetables (mainly beans and legumes, 16-21\%; Table 6). Similarly, red meats were the most essential contributor to dietary $\mathrm{Zn}$ intake in the study population (30\% of total $\mathrm{Zn}$ intake), followed by grains and grain products and vegetables, with a contribution of 17 and $12 \%$, respectively. Good sources of $\mathrm{Zn}$ were also milk and milk products, where more than $20 \%$ of $\mathrm{Zn}$ intake was coming from products such as cheese and yoghurt (see online supplementary material, Supplemental Table 1). The intakes of both $\mathrm{Fe}$ and $\mathrm{Zn}$ were correlated with the intakes of certain food groups.

The most noteworthy correlations among the various food groups were those for grain products $(r=0.43$ for $\mathrm{Fe}$ and $r=0.28$ for $\mathrm{Zn}$, both $P<0.001)$, vegetables $(r=0.33$ for Fe and $r=0.22$ for $\mathrm{Zn}$, both $P<0.001)$ and meat ( $r=0.25$ for Fe and $r=0.41$ for $\mathrm{Zn}$, both $P<0.001$ ). The intakes of $\mathrm{Fe}$ and $\mathrm{Zn}$ were correlated with energy intake ( $r=0.56$ and $r=0.45$, respectively, both $P<0.001$ ).

\section{Contribution of grains and pulses to total iron and zinc intakes}

Phytate in the diet comes mainly from cereal grains, grain products and legumes. White bread and wheat flour are two of the most consumed cereal foods in the Serbian diet and beans and peas are the most commonly used legumes by our study participants (see online supplementary material, Supplemental Tables 2 and 3 for the top ten foods from the cereals and legumes food groups contributing to $\mathrm{Fe}$ and $\mathrm{Zn}$ intakes).

The negative effect of phytic acid on $\mathrm{Zn}$ absorption follows a dose-dependent response, and the molar ratio of phytate to $\mathrm{Zn}$ of a diet can be used to predict the proportion of absorbable dietary $\mathrm{Zn}^{(41)}$.

Due to inadequate dietary data on the phytate content of foods in Serbian databases, we were not able to calculate phyate:Zn molar ratios. However, we employed the method by Jati et al. ${ }^{(42)}$ to determine the bioavailability (Table 7) and confirmed that there is a high bioavailability of both minerals in participants' diets.

\section{Correlation between zinc and iron intakes and status and iron biochemical parameters}

Mean plasma $\mathrm{Zn}$ and Fe status of our study population appeared adequate in spite of the lower dietary intake of these minerals (Table 5).

Intakes of $\mathrm{Fe}$ and $\mathrm{Zn}$ were strongly correlated $(r=0.57$, $P=0 \cdot 001$ ), while the correlations between biochemical parameters and Fe and $\mathrm{Zn}$ dietary intakes were weak. The plasma $\mathrm{Zn}$ concentration did not reflect $\mathrm{Zn}$ intake $(P=0 \cdot 81)$. Women below 50 years of age are the most vulnerable group for development of Fe deficiencies due to increased requirements (menstrual bleeding) and increased need for Fe, and also very often poor intake and poor bioabsorption of Fe. Out of 142 women for whom biochemical data were available, about $23 \%$ had lower $\mathrm{Hb}$ concentration $(<120 \mathrm{~g} / \mathrm{l})$.

There was a statistically significant difference in the intake of $\mathrm{Zn}$ between the groups of women with different $\mathrm{Hb}$ concentrations $(P=0.01$; Table 8) with no variation in any biochemical or anthropometrical indicators measured.

\section{Effect of lifestyle factors on iron and zinc intakes and status}

Plasma $\mathrm{Zn}$ levels ranged from 0.72 to $1.67 \mathrm{mg} / \mathrm{dl}$ in males and from 0.78 to $1.64 \mathrm{mg} / \mathrm{dl}$ in females. Mean plasma concentrations of $\mathrm{Fe}$ and $\mathrm{Zn}$ were different between males and females $(P<0.05$ and $P=0 \cdot 02$, respectively). Likewise, the $\mathrm{Fe}$ and $\mathrm{Zn}$ dietary intakes were genderdependent. Generally, mean dietary intake levels of Fe and $\mathrm{Zn}$ were significantly higher in males compared with 
Table 5 Effect of age, gender, educational level, obesity, marital status, socio-economic status, and iron and zinc intake adequacy on mean daily crude iron and zinc dietary intakes, iron-related biochemical parameters and plasma concentrations of iron and zinc in apparently healthy Serbian adults, June 2013-January 2015

\begin{tabular}{|c|c|c|c|c|c|c|c|c|c|c|c|c|c|c|c|c|c|c|}
\hline & \multicolumn{6}{|c|}{ Dietary intakes } & \multicolumn{12}{|c|}{ Biochemical parameters } \\
\hline & \multirow[b]{2}{*}{$n$} & \multirow[b]{2}{*}{$\%$} & \multicolumn{2}{|c|}{$\mathrm{Fe}(\mathrm{mg} / \mathrm{d})$} & \multicolumn{2}{|c|}{$\mathrm{Zn}(\mathrm{mg} / \mathrm{d})$} & \multirow[b]{2}{*}{$n$} & \multirow[b]{2}{*}{$\%$} & \multicolumn{2}{|c|}{ Haematocrit (I/l) } & \multicolumn{2}{|c|}{$\mathrm{Hb}(\mathrm{g} / \mathrm{l})$} & \multicolumn{2}{|c|}{ Erythrocyte count $\left(\times 10^{12} / \mathrm{l}\right)$} & \multicolumn{2}{|c|}{ Plasma Fe (mg/dl) } & \multicolumn{2}{|c|}{ Plasma Zn (mg/dl } \\
\hline & & & Mean & SD & Mean & SD & & & Mean & SD & Mean & SD & Mean & SD & Mean & SD & Mean & SD \\
\hline \multicolumn{19}{|l|}{ Gender } \\
\hline Male & 128 & 17 & $11 \cdot 6^{\star \star \star}$ & $5 \cdot 4$ & $9 \cdot 1^{\star \star \star}$ & 4.6 & 31 & 38 & $0.4^{\star \star \star}$ & 0.04 & $150 \cdot 6^{\star \star \star}$ & $10 \cdot 9$ & $5 \cdot 1^{\star \star \star}$ & 0.4 & $1 \cdot 3^{\star}$ & 0.4 & $1 \cdot 1^{*}$ & 0.2 \\
\hline Female & 626 & 83 & 9.5 & 4.4 & 7.3 & 3.8 & 51 & 62 & 0.4 & 0.03 & $127 \cdot 1$ & 11.4 & 4.5 & 0.4 & 1.3 & 0.9 & 1.0 & 0.2 \\
\hline \multicolumn{19}{|l|}{ Age years) } \\
\hline $20-29$ & 231 & 31 & 9.5 & 3.5 & 7.5 & $2 \cdot 9$ & 3 & 4 & 0.4 & 0.03 & $131 \cdot 3$ & $9 \cdot 1$ & $4 \cdot 3$ & 0.5 & 1.6 & 0.6 & 1.0 & 0.1 \\
\hline $30-39$ & 197 & 26 & $10 \cdot 0$ & $5 \cdot 2$ & $7 \cdot 4$ & $3 \cdot 3$ & 28 & 34 & 0.4 & $0 \cdot 1$ & $141 \cdot 6$ & $18 \cdot 1$ & 4.9 & 0.6 & $1 \cdot 1$ & 0.5 & $1 \cdot 1$ & 0.2 \\
\hline $40-49$ & 154 & 20 & $9 \cdot 7$ & 4.4 & $7 \cdot 8$ & 4.5 & 38 & 46 & 0.4 & 0.03 & $133 \cdot 7$ & $13 \cdot 1$ & $4 \cdot 7$ & 0.4 & $1 \cdot 3$ & 0.7 & $1 \cdot 1$ & 0.2 \\
\hline $50-59$ & 118 & 16 & $10 \cdot 4$ & $5 \cdot 5$ & $8 \cdot 2$ & 5.9 & 13 & 16 & 0.4 & 0.05 & $131 \cdot 8$ & $18 \cdot 2$ & 4.5 & 0.6 & 1.6 & $1 \cdot 1$ & 1.0 & $0 \cdot 1$ \\
\hline $60-69$ & 54 & 7 & 10.2 & $5 \cdot 3$ & 6.9 & 3.5 & 0 & & & & & & & & & & & \\
\hline \multicolumn{19}{|l|}{ Obesity (BMI) } \\
\hline Obese $(\geq 30.0)$ & 79 & 10 & $10 \cdot 4^{*}$ & 4.7 & $8 \cdot 2$ & $4 \cdot 3$ & 26 & 32 & 0.4 & 0.04 & 138.5 & $17 \cdot 8$ & $4 \cdot 8$ & $0 \cdot 6$ & $1 \cdot 3$ & 0.4 & $1 \cdot 1$ & 0.2 \\
\hline \multirow{2}{*}{\multicolumn{19}{|c|}{ Fe intake adequacy }} \\
\hline & & & & & & & & & & & & & & & & & & \\
\hline Adequate & 538 & $11 \cdot 3^{\star \star *}$ & 4.7 & $8 \cdot 4^{\star \star *}$ & $4 \cdot 3$ & 70 & 85 & $0.4^{*}$ & 0.04 & $137.5^{\star}$ & $16 \cdot 6$ & $4 \cdot 8$ & 0.5 & $1 \cdot 3$ & 0.6 & $1 \cdot 1$ & 0.2 & \\
\hline Inadequate & 215 & $6 \cdot 3$ & 1.4 & 5.5 & 1.9 & 12 & 15 & 0.4 & 0.03 & $127 \cdot 4$ & $7 \cdot 3$ & 4.5 & 0.4 & $1 \cdot 3$ & $1 \cdot 3$ & $1 \cdot 1$ & 0.2 & \\
\hline \multicolumn{19}{|l|}{$\mathrm{Zn}$ intake adequacy } \\
\hline Adequate & 360 & $11 \cdot 5^{\star \star \star}$ & $5 \cdot 2$ & $10 \cdot 1^{\star \star \star}$ & $4 \cdot 3$ & 52 & 63 & $0.4^{*}$ & 0.05 & $137 \cdot 1^{\star}$ & $16 \cdot 8$ & $4 \cdot 8$ & 0.5 & $1 \cdot 3$ & 0.6 & $1 \cdot 0$ & 0.2 & \\
\hline Inadequate & 393 & $8 \cdot 3$ & $3 \cdot 4$ & $5 \cdot 3$ & 1.5 & 30 & 37 & 0.4 & 0.04 & $134 \cdot 2$ & $14 \cdot 7$ & 4.6 & 0.5 & $1 \cdot 3$ & 0.9 & $1 \cdot 1$ & 0.2 & \\
\hline \multicolumn{19}{|c|}{ Socio-economic status } \\
\hline Low income & 247 & 33 & $10 \cdot 5^{\star}$ & $5 \cdot 5$ & 7.5 & 3.4 & 0 & 0 & & - & - & & & & & & & \\
\hline Affluent & 507 & 67 & 9.5 & $4 \cdot 1$ & $7 \cdot 7$ & $4 \cdot 2$ & 82 & 100 & 0.4 & 0.04 & $136 \cdot 0$ & $16 \cdot 0$ & 4.7 & 0.5 & $1 \cdot 3$ & 0.7 & $1 \cdot 1$ & 0.2 \\
\hline \multicolumn{19}{|l|}{ Education } \\
\hline Primary & 58 & 8 & $10 \cdot 5$ & $5 \cdot 4$ & $7 \cdot 2$ & 3.4 & 1 & 1 & \multicolumn{2}{|c|}{0.4} & \multicolumn{2}{|c|}{125} & \multicolumn{2}{|c|}{4.5} & \multicolumn{2}{|c|}{0.6} & & \\
\hline Secondary & 443 & 59 & 9.7 & 4.7 & $7 \cdot 3$ & 3.0 & 17 & 21 & 0.4 & 0.04 & $132 \cdot 6$ & $13 \cdot 7$ & 4.7 & 0.4 & $1 \cdot 3$ & 0.6 & $1 \cdot 1$ & 0.2 \\
\hline Tertiary & 253 & 34 & 9.9 & $4 \cdot 2$ & $8 \cdot 2$ & $5 \cdot 3$ & 64 & 78 & 0.4 & 0.05 & $137 \cdot 1$ & $16 \cdot 6$ & 4.7 & 0.5 & $1 \cdot 3$ & 0.7 & $1 \cdot 1$ & 0.2 \\
\hline Marital status & & & & & & & & & & & & & & & & & & \\
\hline Married & 383 & 51 & 9.9 & 4.7 & $7 \cdot 7$ & 4.7 & 55 & 67 & 0.4 & 0.04 & $134 \cdot 6$ & $16 \cdot 5$ & 4.7 & 0.5 & $1 \cdot 3$ & 0.8 & $1 \cdot 1$ & 0.2 \\
\hline Single & 203 & 27 & 9.7 & $4 \cdot 1$ & 7.5 & 2.9 & 18 & 22 & 0.4 & 0.05 & 138.7 & $16 \cdot 9$ & 4.8 & 0.5 & 1.3 & 0.5 & 1.0 & 0.2 \\
\hline Other & 168 & 22 & $10 \cdot 1$ & $6 \cdot 2$ & $7 \cdot 3$ & $3 \cdot 3$ & 9 & 11 & 0.4 & 0.03 & $139 \cdot 6$ & 9.9 & 4.9 & 0.4 & 1.0 & 0.3 & $1 \cdot 1$ & 0.2 \\
\hline
\end{tabular}

Plasma Fe and Zn concentrations determined by flame atomic absorption spectrometry analysis.

Between-factor comparison (using the Kruskal-Wallis test for factors with more than two categories and the Wilcoxon test for factors with two categories): ${ }^{\star} P<0.05$, ${ }^{\star \star \star} P<0.001$. 
Table 6 Contribution (\%) of the main food groups to total zinc and iron intakes of apparently healthy Serbian adults, June 2013-January 2015

\begin{tabular}{|c|c|c|c|c|c|c|}
\hline & \multicolumn{3}{|c|}{$\mathrm{Fe}$} & \multicolumn{3}{|c|}{$\mathrm{Zn}$} \\
\hline & Males & Females & Total & Males & Females & Total \\
\hline Meat and meat products & $17 \cdot 9$ & $16 \cdot 7$ & $17 \cdot 2$ & $35 \cdot 2$ & $29 \cdot 2$ & $30 \cdot 6$ \\
\hline Milk and milk products & 1.9 & 2.4 & $2 \cdot \overline{3}$ & 20.0 & $22 \cdot \overline{6}$ & $22 \cdot 2$ \\
\hline Grains and grain products & $30 \cdot 1$ & $32 \cdot 8$ & 32.6 & 13.9 & $17 \cdot 3$ & $16 \cdot 6$ \\
\hline Vegetable and vegetable products & 14.9 & 11.4 & $12 \cdot 3$ & 11.2 & 7.7 & 8.3 \\
\hline Legumes & $6 \cdot 1$ & 4.8 & $5 \cdot 1$ & 3.6 & 2.9 & $3 \cdot 1$ \\
\hline Egg and egg products & $5 \cdot 1$ & 3.5 & $3 \cdot 8$ & 4.9 & 3.9 & $4 \cdot 1$ \\
\hline Nuts, seeds, kernel products & 8.4 & 9.6 & 9.4 & 3.1 & 3.5 & $3 \cdot 3$ \\
\hline Beverages (non-milk) & 4.2 & 4.9 & 4.8 & $2 \cdot 0$ & 3.2 & 3.0 \\
\hline Seafood and related products & 2.4 & 2.6 & 2.6 & 1.6 & $3 \cdot 1$ & 2.7 \\
\hline Fruit and fruit products & 3.4 & 4.6 & 4.4 & 1.7 & $2 \cdot 4$ & $2 \cdot 2$ \\
\hline Sugar and sugar products & 3.3 & 3.9 & $2 \cdot 6$ & 1.9 & $2 \cdot 1$ & $2 \cdot 1$ \\
\hline Miscellaneous food products & 1.9 & $2 \cdot 6$ & 2.5 & 1.0 & $2 \cdot 0$ & 1.8 \\
\hline Fats and oils & 0.3 & 0.3 & 0.3 & 0.0 & 0.1 & 0.1 \\
\hline
\end{tabular}

Table 7 Assessment of the bioavailability of zinc and iron in the diets of apparently healthy Serbian adults, June 2013-January 2015

\begin{tabular}{lcc}
\hline & Males & Females \\
\hline Total energy (kJ) & 8916 & 7182 \\
Total energy (kcal) & $2131 \cdot 0$ & 1716.5 \\
Energy from protein from fish \& meat (kJ) & 625 & 417 \\
Energy from protein from fish \& meat (kcal) & 149.3 & 99.6 \\
Energy from protein from fish \& meat (\%TE) & $7 \cdot 0$ & $5 \cdot 8$ \\
Energy from grains \& nuts \& pulses (kJ) & 2923 & 2654 \\
Energy from grains \& nuts \& pulses (kcal) & $698 \cdot 6$ & 634.4 \\
Energy from grains \& nuts \& pulses (\%TE) & $32 \cdot 8$ & 36.9 \\
Fe bioavailability (\%) & 15 & 15 \\
Zn bioavailability & High & High \\
\hline
\end{tabular}

$\% \mathrm{TE}$, percentage of total energy.

The method of Jati et al. ${ }^{(42)}$ was applied.

Table 8 Dissimilarities in various parameters among apparently healthy Serbian women with low and high $\mathrm{Hb}$ concentration, June 2013-January 2015

\begin{tabular}{|c|c|c|c|c|c|c|c|}
\hline & \multicolumn{2}{|c|}{$\begin{array}{l}\text { Females } \\
(n \text { 142) }\end{array}$} & \multicolumn{2}{|c|}{$\begin{array}{l}\text { Low Hb } \\
(n 33)\end{array}$} & \multicolumn{2}{|c|}{$\begin{array}{l}\text { High } \mathrm{Hb} \\
(n \text { 108) }\end{array}$} & \multirow[b]{2}{*}{$P$ value } \\
\hline & Mean & SD & Mean & $\mathrm{SD}$ & Mean & SD & \\
\hline Ige & $23 \cdot 3$ & 0.8 & $30 \cdot 2$ & $10 \cdot 5$ & 23.0 & 0.8 & \\
\hline Weight $(\mathrm{kg})$ & $60 \cdot 3$ & 5.5 & $67 \cdot 2$ & $10 \cdot 3$ & 61.0 & $5 \cdot 0$ & \\
\hline Height $(\mathrm{cm})$ & $169 \cdot 9$ & 4.4 & 169.5 & $6 \cdot 0$ & $170 \cdot 7$ & $4 \cdot 1$ & \\
\hline BMI $\left(\mathrm{kg} / \mathrm{m}^{2}\right)$ & 20.9 & 1.4 & 23.4 & 3.8 & $20 \cdot 9$ & 1.3 & \\
\hline WC $(\mathrm{cm})$ & $72 \cdot 0$ & 4.4 & $76 \cdot 4$ & 9.8 & $72 \cdot 8$ & 4.4 & \\
\hline $\mathrm{Hb}(\mathrm{g} / \mathrm{l})$ & $130 \cdot 4$ & $10 \cdot 7$ & $112 \cdot 4$ & $7 \cdot 8$ & $135 \cdot 0$ & $8 \cdot 1$ & \\
\hline Haematocrit $(1 / /)$ & 0.4 & 0.0 & 0.4 & 0.0 & 0.4 & 0.0 & \\
\hline $\begin{array}{l}\text { Erythrocyte } \\
\text { count }\left(\times 10^{12} / I\right)\end{array}$ & 4.4 & 0.3 & $4 \cdot 2$ & 0.3 & 4.5 & 0.3 & \\
\hline $\mathrm{Fe}(\mu \mathrm{mol} / \mathrm{l})$ & $15 \cdot 8$ & 4.8 & $12 \cdot 5$ & $6 \cdot 1$ & $16 \cdot 5$ & 4.5 & \\
\hline Dietary Fe $(\mathrm{mg} / \mathrm{d})$ & $9 \cdot 6$ & $5 \cdot 1$ & $10 \cdot 2$ & 4.1 & 9.5 & 4.5 & 0.036 \\
\hline Dietary $\mathrm{Zn}(\mathrm{mg} / \mathrm{d})$ & $7 \cdot 1$ & $2 \cdot 2$ & 9.0 & 5.5 & $7 \cdot 3$ & $2 \cdot 2$ & 0.010 \\
\hline
\end{tabular}

Low $\mathrm{Hb}, \mathrm{Hb}$ value below $120 \mathrm{~g} / \mathrm{l}$; WC, waist circumference.

Dietary $\mathrm{Fe}$ and $\mathrm{Zn}$ data were obtained from $24 \mathrm{~h}$ recalls. Only significant $P$ values are given.

females, being approximately $20 \%$ higher in males. Similarly, $\mathrm{Hb}$ concentration and plasma concentrations of $\mathrm{Fe}$ and $\mathrm{Zn}$ were higher in males than in females (Table 5). We did not observe any differences in the $\mathrm{Zn}$ and Fe intake or status data within different age groups $(P=0 \cdot 16)$.

Fe intake was related to BMI $(P<0 \cdot 05)$, while $\mathrm{Zn}$ intake was not different between obese and non-obese individuals $(P=0 \cdot 07)$. No correlation was seen between $\mathrm{BMI}$ and $\mathrm{Fe}$ and $\mathrm{Zn}$ status $(P=0.44$ and $P=0.25$, respectively). We estimated the degree of association between biochemical parameters (plasma Fe, $\mathrm{Hb}$, erythrocyte count and plasma $\mathrm{Zn}$ ), energy and protein intakes and lifestyle factors, and did not detect any significant associations.

No association was found between dietary Fe and Zn intakes and education level or marital status (Table 5). Similarly, components of socio-economic status (SES) measured in the study showed no correlation with any of the biochemistry-related parameters, including Fe and $\mathrm{Zn}$ status. However, there was a statistically significant difference in $\mathrm{Fe}$ intake between the low-income and affluent participants $(P=0.034)$, while no such difference was observed for $\mathrm{Zn}$ intake $(P=0 \cdot 084)$.

Differences were also observed in the intake of $\mathrm{Fe}$ between the affluent and low-income female groups $(P=0 \cdot 005$; Table 5). Finally, there was a statistically significant difference in $\mathrm{Hb}$ concentration between the groups of women with $\mathrm{Zn}$ adequate and $\mathrm{Zn}$ inadequate diets.

\section{Discussion}

The results of the current study demonstrate that inadequate intake of $\mathrm{Zn}$ was present in a healthy population cohort. There was no strong relationship between dietary $\mathrm{Zn}$ intake and Fe biochemical parameters in this healthy cohort. However, there was a statistically significant difference in $\mathrm{Zn}$ intake among groups of women with dissimilar $\mathrm{Hb}$ concentration. $\mathrm{Zn}$ and $\mathrm{Fe}$ dietary intakes were strongly correlated. Grains and meat were identified as major sources of dietary Fe intake and meat and dairy products as main foods consumed contributing to $\mathrm{Zn}$ 
intake. Generally, no differences were seen for Fe and Zn intakes and status among various SES groups, except for $\mathrm{Fe}$ intake between those on low income and affluent. Plasma Zn and Fe concentrations were within the reference ranges despite the insufficient dietary intakes of these minerals. However, a prolonged inadequate intake of $\mathrm{Zn}$ and Fe may contribute to the development/manifestation of $\mathrm{Zn}$ and/or Fe deficiencies, so regular monitoring of mineral intake and status in this population cohort is necessary.

The mean $\mathrm{Fe}$ and $\mathrm{Zn}$ intakes of our study population were similar to the values for these elements reported for the adult population in other developed countries: Hungary, Croatia, Eastern and Central European countries, Australia and Canada ${ }^{(29,43-45)}$.

A recent review of available micronutrient intake and status data in Europe ${ }^{(29)}$ showed that Fe and $\mathrm{Zn}$ intake data for a number of countries are very limited. More current measurements of adult $\mathrm{Fe}$ and $\mathrm{Zn}$ intake and status data are rare ${ }^{(46)}$. In this sense, results presented in the current study can be considered a valuable resource.

The intakes of $\mathrm{Fe}$ and $\mathrm{Zn}$ were different between males and females, and there was a strong correlation between $\mathrm{Zn}$ and Fe intakes, which is in agreement with previous reports ${ }^{(47-49)}$. There was also a positive correlation between mineral intakes and energy and this relationship has been highlighted by others ${ }^{(28,50)}$. The EAR cut-point method was used to assess the adequacy of Fe and $\mathrm{Zn}$ intakes. The EAR cut-point method is identified as an appropriate dietary reference intake to use when assessing the adequacy of group intakes and has been adopted for assessing nutrient inadequacy ${ }^{(51)}$. In addition, we also compared the intake data with other available dietary recommendations ${ }^{(52,53)}$ and showed that the risk of inadequate intakes was very different. The fact that the method employed can affect the estimation of nutrient intake inadequacy ${ }^{(53,54)}$ has been confirmed again. The Nordic and FAO/WHO recommendations overestimate the true prevalence of inadequate intake compared with the EAR cut-point method. Still, it must be noted that while intakes below the recommendation are not synonymous with deficiency, they certainly indicate increased risk of deficiency $^{(54)}$.

The estimation of and adjustment for bias (such as under- or over-reporting of food intake) is a relatively unexplored field. An evaluation of the effect of misreporting on energy and nutrient intake assessment indicated that low energy reporters had lower mean intakes for several micronutrients (from 25 to $36 \%$ ) compared with non-under-reporters ${ }^{(55)}$. Likely under-reporting of food consumption was estimated to occur in $34 \%$ (260/754) of the present study participants. Of our study population, $28 \%$ had low Fe intake and $52 \%$ had $\mathrm{Zn}$ intake below current dietary recommendations ${ }^{(33)}$. Taking under-reporting into account, it is estimated that $5 \%$ of the study population had inadequate $\mathrm{Fe}$ and $15-25 \%$ had unsatisfactory $\mathrm{Zn}$ intake. Sixty-five per cent of our study population were women within the age range of 20-50 years. Women in this age group are known as the most vulnerable group for the development of Fe and $\mathrm{Zn}$ deficiencies because they are more likely to have excessive menstrual bleeding, infrequently consume sources of bioavailable $\mathrm{Zn}$ and $\mathrm{Fe}$, rarely consume rich sources of enhancers and often consume rich sources of inhibitors of $\mathrm{Zn}$ and $\mathrm{Fe}$ absorption ${ }^{(56)}$. We found that women with dietary Fe intake below recommendations (EAR of $8.1 \mathrm{mg} / \mathrm{d}$ ) were at greater risk of inadequate dietary $\mathrm{Zn}$ intake: $38 \%$ of women in the present study had inadequate dietary Fe intake and $76 \%$ of these with low dietary Fe intake show concurrent insufficient intake of $\mathrm{Zn}$.

In many developed countries, micronutrient deficiencies are not related to the quantity of food consumed, but rather to the quality of the diet ${ }^{(57)}$. Inadequate dietary intakes of $\mathrm{Zn}$ and Fe that failed to meet the high physiological demands of adolescent girls in Australia and New Zealand were shown to be related to food choices ${ }^{(3)}$. Relevant to these findings is the observation in fifty-two non-pregnant premenopausal women from Seattle, Washington, USA, whose diets provided similar amounts of Fe, where the consumption of red meat five times per week was more efficacious for body Fe stores than the consumption of lacto-ovo vegetarian foods, or the flesh of chicken and fish ${ }^{(58)}$. In further support of this are the findings of the National Food Survey of the British population $^{(59)}$ showing that Fe intake and red meat consumption have declined during the past three decades, leading to low Fe stores in females aged 11-64 years.

Being overweight is a worldwide problem that affects developed and developing countries similarly ${ }^{(37,40)}$. Approximately $30 \%$ of our study population was overweight and $10 \%$ were obese. Other European countries have shown a similar percentage of overweight and obesity $^{(37)}$. However, even with excess dietary intake of energy and macronutrients, it is still uncertain if people are taking the recommended intakes of micronutrients. For instance, a number of national epidemiological surveys conducted in several developed countries have reported the co-occurrence of obesity with inadequate intakes of certain vitamins and minerals, particularly $\mathrm{Ca}, \mathrm{Fe}, \mathrm{Zn}$, thiamin, riboflavin, vitamins $\mathrm{B}_{6}$ and $\mathrm{D}$, and folate ${ }^{(15,60,61)}$.

In the present study we found higher intake of $\mathrm{Fe}$ in the obese population than in non-obese individuals. A possible explanation for the higher intake of $\mathrm{Fe}$ in obese people is that their energy intake was higher because of the greater consumption of fatty (energy-dense) foods (i.e. meats) and refined grain products (white bread is a staple food). The correlations of energy intake, total grain products and meat with Fe intake support this explanation. However, not only inappropriate intakes, but also impaired bioavailability and utilization of micronutrients may be involved in the inadequate micronutrient status in obesity. The low-level inflammation that accompanies 
obesity is likely to decrease Fe absorption ${ }^{(62)}$. This needs to be taken into account when evaluating the adequacy of Fe intake in a population.

$\mathrm{Zn}$ and Fe nutrition are often associated. Red meat and grain products are the most important common dietary sources of $\mathrm{Fe}$ and $\mathrm{Zn}$. Our findings confirm observations that food sources of $\mathrm{Zn}$ are also important food sources of $\mathrm{Fe}$, as well as support the theory that usual low intake of either mineral increases the likelihood of low intake of the other $^{(3,17,18)}$. Furthermore, other factors influence daily intakes of $\mathrm{Zn}$ and Fe: their concentration in food, the amount of food consumed and the consumption of dietary components that delay $\mathrm{Fe}$ and $\mathrm{Zn}$ absorption ${ }^{(23)}$. Zn and Fe are most bioavailable from many of the same foods and their absorption is repressed by many of the same dietary substances $^{(56)}$. Although we were not able to estimate the exact phytate:Zn molar ratio of the diets, by employing the method of Jati et al. ${ }^{(42)}$ we showed that there was a high bioavailability of both nutrients in the diets of the people we studied. The food composition database needs to be updated because, as in many other databases, our data did not contain information on the content of phytate.

Food preparation and processing methods can be used to reduce the phytate content of foods based on cereals and legumes. These methods are based on the enzymatic hydrolysis of phytic acid to lower inositol phosphates that are induced by germination and fermentation ${ }^{(26)}$. Soaking, followed by empting out of the soaking water, can also be used to reduce the phytate content of cereal and legume flours by passive diffusion of the water-soluble sodium, potassium and magnesium phytates ${ }^{(63)}$. Household-level information was obtained for people where cereals and legumes contributed a large proportion to total $\mathrm{Fe}$ and $\mathrm{Zn}$ intakes. Almost all of our participants (97\%) employed preparation techniques that are known to reduce phytate content of foods and increase $\mathrm{Zn}$ bioavailability (i.e. soaking of beans, fermentation of bread dough).

Overall, the plasma concentrations of Fe and $\mathrm{Zn}$ in the present study were within the expected normal ranges for the adult population and similar to reported levels of these elements in healthy individuals elsewhere ${ }^{(64,65)}$. Similarly, the mean values of Fe-related biochemical parameters were within the expected ranges for a healthy population of subjects ${ }^{(64,66,67)}$. Mean plasma levels of both elements were significantly different between males and females. Obesity, age, education and marital status did not contribute to the differences in plasma levels of the studied minerals. These findings are in agreement with the results of Sian et al. ${ }^{(68)}$, Bailey et al. ${ }^{(69)}$ and Sanchez et al. ${ }^{(28)}$.

Our observation of a strong association between usual $\mathrm{Fe}$ and $\mathrm{Zn}$ intakes was not accompanied by a similar relationship between $\mathrm{Fe}$ and $\mathrm{Zn}$ status. The lack of association may be due to several factors.

First, the inter-individual variation in biological availability of dietary Fe and $\mathrm{Zn}$ is determined by the degree of intestinal absorption that depends on the composition of meals; the absorption from two different meals with similar $\mathrm{Fe} / \mathrm{Zn}$ content may vary considerably due to the interaction between dietary $\mathrm{Fe} / \mathrm{Zn}$ and absorption enhancers and inhibitors ${ }^{(70,71)}$. It could also be that good homeostatic regulation of $\mathrm{Zn}$ contributes to these dissimilarities $^{(44,72)}$. Second, the calculation of reported dietary intake is performed using food composition tables (calculated and chemically measured content of the diet may be different). Finally, the reported intake of dietary $\mathrm{Zn}$ and Fe may deviate to some degree from the true intake due to diet reporting error. In the present study we attempted to correct for some of these discrepancies by taking under-reporting into account; however, we need to acknowledge that a certain level of error may still be present.

The correlation of $\mathrm{Zn}$ intake and $\mathrm{Zn}$ status with $\mathrm{Fe}$ biochemical parameters in healthy populations has not been investigated widely. Only a few studies have been initiated and provide inconsistent results ${ }^{(28,73,74)}$. Various studies in Fe- and Zn-deficient populations have shown a positive link between $\mathrm{Zn}$ intake and $\mathrm{Fe}$ status indicators ${ }^{(6,27)}$. In our healthy population cohort we did not find any significant correlation, most likely due to having a small number of people with inadequate Fe status. Still, it was evident that $\mathrm{Hb}$ concentration was statistically different between women with appropriate and insufficient $\mathrm{Zn}$ intakes. Further work may be needed to examine the role of dietary $\mathrm{Zn}$ on Fe status indicators more fully. Measurements of ferritin, transferrin and total Fe-binding capacity may provide more detailed analysis of this relationship as low $\mathrm{Hb}$, which was used in the present study, is not the best indicator of Fe status and is mainly apparent during the late stages of Fe deficiency. In addition, as a number of studies over the years have demonstrated the positive link between $\mathrm{Zn}$ intake and Fe status and the role of $\mathrm{Zn}$ in the $\mathrm{Fe}$ absorption process ${ }^{(21,27,73,75)}$, further work in this area should aim to elucidate the specific point in Fe deficiency progression when inadequate $\mathrm{Zn}$ intake is beginning to have its role.

As shown by many, SES, conventionally measured by education, occupation or inco.me, can contribute to inequalities in health ${ }^{(76,77)}$. Those with limited incomes or lower educational levels are more likely to have poor-quality diets ${ }^{(78)}$. Energy-dense and nutrient-poor diets are cheap and usually consumed by those with limited budgets ${ }^{(77)}$.

A limited number of studies have shown inconsistent results on the variation in $\mathrm{Fe}$ and $\mathrm{Zn}$ intakes between SES groups. Higher (2-5\%) Zn levels were found in low-SES groups ${ }^{(28,79)}$, while others found no differences among the groups ${ }^{(80)}$. Similarly, higher values of plasma Fe have been reported in high-SES groups ${ }^{(81,82)}$, while again there are studies that showed no differences in Fe intake or status among various SES groups ${ }^{(83)}$.

In the current study we looked at the association of marital status, educational level and occupation with Fe and $\mathrm{Zn}$ intakes and status, and found no differences in 
intake or status between SES groups. The only difference was seen in the intake of $\mathrm{Fe}$ between the affluent and those on poor income, which is most likely due to higher consumption of grain products and pulses (staple foods) by people in the low-income group.

The findings of the current study should be interpreted in view of its strengths and limitations. The strength of our study is that we investigated a homogeneous population with similar demographic and genetic background. In this way, we were able to look at the influence of nutrition on $\mathrm{Fe}$ and $\mathrm{Zn}$ intakes and status and their relationship in the healthy adult population. Another strong point of our work is the collection of dietary data. We administered three $24 \mathrm{~h}$ recall questionnaires, on three non-consecutive days, which is the gold standard method for assessing the adequacy of $\mathrm{Fe}$ and $\mathrm{Zn}$ intakes ${ }^{(84)}$.

We identify a few limitations of the present study. Plasma (serum) $\mathrm{Zn}$ is a good indicator of $\mathrm{Zn}$ deficiency; however, plasma $\mathrm{Zn}$ levels do not reflect marginal status and may not reflect dietary intakes ${ }^{(85)}$. Plasma $\mathrm{Zn}$ is insensitive to $\mathrm{Zn}$ intakes within this range ${ }^{(71,86)}$, and the Institute of Medicine ruled out plasma $\mathrm{Zn}$ as a useful status indicator for evaluating human $\mathrm{Zn}$ requirements for Canada and the USA ${ }^{(33)}$. It is also accepted that plasma $\mathrm{Zn}$ concentration is a valid indicator of whole-body $\mathrm{Zn}$ status in the absence of confounding factors, such as infection or stress ${ }^{(87)}$. Nevertheless, with all its limitations, it is the best biomarker currently available. Studies have pointed out that the ratio of blood fatty acids (linoleic acid:dihomo- $\gamma$ linolenic acid) may be a more appropriate biomarker of $\mathrm{Zn}$ status that is able to differentiate between various $\mathrm{Zn}$ deficiency/adequacy states ${ }^{(88,89)}$; however, additional research is needed to fully determine the efficacy of this biomarker. Another weakness of our study was the inability to calculate the phytate:Zn molar ratios due to the lack of available data on phytate content of foods in our database. However, we believe that this was overcome by estimating the bioavailability of $\mathrm{Fe}$ and $\mathrm{Zn}$ using the method of Jati et al. ${ }^{(42)}$.

In countries where fresh vegetables, fruits and proteins are freely available and well embodied in the average diet, as is the case in many European countries, nutritional deficiencies of $\mathrm{Fe}$ and $\mathrm{Zn}$ are expected to be rare. However, easy access to food does not ensure healthy food choices required to achieve adequate nutrition ${ }^{(57)}$. Similarly, lifestyle changes occurring over the last few decades in many developed countries are characterized by increased consumption of low-cost but energy-dense foods and by reduced physical activity levels. These lifestyle changes are the major factors implicated in the aetiology of the current obesity epidemic ${ }^{(90)}$. It is well known that an unbalanced diet can contribute to micronutrient malnutrition ${ }^{(91)}$. Dietary decisions made by individuals may lead to $\mathrm{Fe}$ and $\mathrm{Zn}$ deficiencies. Finally, with the present global trend of people in developed countries to decrease meat intake and increase intake of grains, there is a tendency that more individuals may end up having inadequate intakes of these important minerals.

In conclusion, considering that more than $20 \%$ of our study population had inadequate dietary intake of $\mathrm{Zn}$ and bearing in mind the health consequences of prolonged inappropriate $\mathrm{Zn}$ intake on both $\mathrm{Zn}$ and $\mathrm{Fe}$ nutritional status, more regular follow-ups are needed to monitor the intake and status of these nutrients and to make sure that potential deficiencies do get recognized and addressed in a timely manner.

\section{Acknowledgements}

Acknowledgements: The authors gratefully thank all volunteers who participated in the study for their cooperation, time and motivation. Financial support: This work was supported by the Ministry of Education and Science of the Republic of Serbia (Grant III 41030); the EU FP7 BACCHUS project (grant agreement number 312090); and an Australian Postgraduate Award Scholarship provided to M.K. The financing organizations had no role in the design, analysis or writing of this article. Conflict of interest: The authors declare no conflict of interest. Authorship: M.K. designed and conducted part of the research, analysed the data, wrote the manuscript and had primary responsibility for the final content. J.C.R.S. designed part of the research and revised the final version of the paper. M.N. was responsible for the statistical analysis. M.Z. helped with dietary intake data and analysis. M.Gu. proofread the paper and provided constructive advice. M.Gl. provided essential materials and revised the final draft the paper. All authors have read the manuscript and approved the final version of the paper. Ethics of human subject participation: All subjects went through the informed consent process, both verbal and written. Verbal consent was witnessed and formally recorded. The study protocols were approved by the Clinical Hospital Centre Zemun, Belgrade, Serbia (ethics committee approval number: 2125, 2013); and by SAC HREC EC00188 (approval number: 96.15), Adelaide, South Australia. The protocols and procedures were in agreement with the ethical guidelines on biomedical research on human subjects of The Code of Ethics of the World Medical Association's Declaration of Helsinki (1964) and its further amendments.

\section{Supplementary material}

To view supplementary material for this article, please visit https://doi.org/10.1017/S1368980017001240

\section{References}

1. Castillo-Duran \& Cassorla F (1999) Trace minerals in human growth and development. J Pediatr Endocrinol Metab 12, 589-601.

2. Lieu PT, Heiskala M, Peterson PA et al. (2001) The roles of iron in health and disease. Mol Aspects Med 2, 1-87. 
3. Gibson RS, Heath AL \& Ferguson EL (2002) Risk of suboptimal iron and zinc nutriture among adolescent girls in Australia and New Zealand: causes, consequences, and solutions. Asia Pac J Clin Nutr 11, Suppl. 3, S543-S552.

4. Stoltzfus RJ (2001) Iron-deficiency anemia: reexamining the nature and magnitude of the public health problem. Summary: implications for research and programs. $J$ Nutr 131, issue 2S-2, 697S-701S.

5. Wuehler SE, Peerson JM \& Brown KH (2005) Use of national food balance data to estimate the adequacy of zinc in national food supplies: methodology and regional estimates. Public Health Nutr 8, 812-819.

6. Gibson RS, Hess SY, Hotz C et al. (2008) Indicators of zinc status at the population level: a review of the evidence. BrJ Nutr 99, Suppl. 3, S14-S23.

7. Greger JL (1989) Current Topics in Nutrition and Disease. vol. 21: Mineral Homeostasis in the Elderly. New York: Liss.

8. Shankar AH \& Prasad AS (1998) Zinc and immune function: the biological basis of altered resistance to infection. Am J Clin Nutr 68, 2 Suppl., 447S-463S.

9. Roman Viñas B, Ribas Barba L, Ngo J et al. (2011) Projected prevalence of inadequate nutrient intakes in Europe. Ann Nutr Metab 59, 84-95.

10. Mensink GBM, Fletcher R, Gurinovic M et al. (2013) Mapping low intake of micronutrients across Europe. Br J Nutr 110, 755-773.

11. Moshfegh A, Goldman J \& Cleveland L (2005) What We Eat in America - NHANES 2001-2002: Usual Nutrient Intakes from Food Compared to Dietary Reference Intakes. Washington, DC: US Department of Agriculture, Agricultural Research Service.

12. Health Canada (2004) Canadian Community Health Survey - Cycle 2.2, Nutrition (2004): Nutrient Intakes from FoodProvincial, Regional and National Data. Ottawa: Health Canada.

13. Henderson L, Irving K, Gregory J et al. (2003) The National Diet and Nutrition Survey: Adults Aged 19 to 64 Years. vol. 3: Vitamin and Mineral Intake and Urinary Analyses. London: The Stationery Office.

14. Paturi $\mathrm{M}$, Tapanainen $\mathrm{H}$, Reinivuo $\mathrm{H}$ et al. (2008) The National FINDIET 2007 Survey. Folkhalsoinstitutes publikationer no. B23/2008. Helsinki: National Public Health Institute.

15. Elmadfa I (2009) European Nutrition and Health Report. Forum Nutr 62, 1-405.

16. Briefel RR, Bialostosky $\mathrm{K}$, Kennedy-Stephenson $\mathrm{J}$ et al. (2000) Zinc intake of the US population: findings from the Third National Health and Nutrition Examination Survey, 1988-1994. J Nutr 130, 5S Suppl., 1367S-1373S.

17. Lee DH, Folsom AR \& Jacobs DR (2005) Iron, zinc, and alcohol consumption and mortality from cardiovascular diseases: the Iowa Women's Health Study. Am J Clin Nutr 81, 787-791.

18. Cole CR, Grant FK, Swaby-Ellis ED et al. (2010) Zinc and iron deficiency and their interrelations in low-income African American and Hispanic children in Atlanta. Am J Clin Nutr 91, 1027-1034.

19. Reeves PG, Briske-Anderson M \& Johnson L (1998) Physiologic concentrations of zinc affect the kinetics of copper uptake and transport in the human intestinal cell model, Caco-2. J Nutr 128, 1794-17801.

20. Davidson L, Almgren A, Sandstrom B et al. (1995) Zinc absorption in adult humans: the effect of iron fortification. Br J Nutr 74, 417-425.

21. Knez M, Graham RD, Welch RM et al. (2015) New perspectives on the regulation of iron absorption via cellular zinc concentrations in humans. Crit Rev Food Sci Nutr 57, 2128-2143.

22. Sandstead HH (1991) Zinc deficiency: a public health problem. Am J Dis Child 145, 835-859.
23. Lonnerdal B (2000) Dietary factors influencing zinc absorption. J Nutr 130, 5S Suppl., S1378-S1383.

24. Nishiyama S, Irisa K, Matsubasa T et al. (1998) Hematological deficits in middle aged women. J Am Coll Nutr 17, 291-295.

25. Prasad AS, Schulert AR, Miale F et al. (1963) Zinc and iron deficiencies in male subjects with dwarfism and hypogonadism but without ancylostomiasis, schistosomiasis or severe anemia. Am J Clin Nutr 12, 437-444.

26. Gibson RS, Heath AL, Prosser N et al. (1999) Are young women with low iron stores at risk of zinc as well as iron deficiency?. In Trace Elements in Man and Animals 10, pp. 323-328 [AM Roussel, RA Anderson and AE Favrier, editors]. New York: Kluwer Academic Publishers.

27. Shamim AA, Kabir A, Merrill RD et al. (2013) The effect of iron and zinc supplementation and its discontinuation on liver antioxidant status in rats fed deficient diets. Public Health Nutr 16, 1354-1361.

28. Sanchez C, Lopez-Jurado M, Planells E et al. (2009) Assessment of iron and zinc intake and related biochemical parameters in an adult Mediterranean population from southern Spain: influence of lifestyle factors. J Nutr Biochem 20, $125-131$.

29. Novaković R, Cavelaars A, Geelen A et al. (2014) Socio-economic determinants of micronutrient intake and status in Europe: a systematic review. Public Health Nutr 17, 1031-1045.

30. Gurinović M, Milešević J, Kadvan A et al. (2016) Establishment and advances in the online Serbian food and recipe data base harmonized with EuroFIR standards. Food Chem 193, 30-38.

31. Glibetic M, Kadvan A, Tepsic J et al. (2011) Management of food composition database harmonized with EuroFIR criteria using a web application. J Food Compost Anal 24, 741-741.

32. Gurinović M, Milešević J, Kadvan A et al. (2016) Development, features and application of DIET ASSESS \& PLAN (DAP) software in supporting public health nutrition research in Central Eastern European Countries (CEEC). Food Chem (Epublication ahead of print version).

33. Institute of Medicine, Food and Nutrition Board (2001) Dietary Reference Intakes for Vitamin A, Vitamin $K$, Arsenic, Boron, Chromium, Copper, Iodine, Iron, Manganese, Molybdenum, Nickel, Silicon, Vanadium, and Zinc. Washington, DC: National Academies Press.

34. Schofield WN (1985) Predicting basal metabolic rate, new standards and review of previous work. Hum Nutr Clin Nutr 39, 5-41.

35. EUROSTAT (2013) Income, Social Inclusion and Living Conditions. http://ec.europa.eu/eurostat/web/microdata/ european-union-statistics-on-income-and-living-conditions (accessed September 2015).

36. Nikolić M, Glibetić M, Gurinović M et al. (2014) Identifying critical nutrient intake in groups at risk of poverty in Europe: the CHANCE Project Approach. Nutrients 6, 1374-1379.

37. World Health Organization \& Food and Agriculture Organization of the United Nations (2013) Global Health Observatory (GHO) data: Overweight and obesity. http:// www.who.int/gho/ncd/risk_factors/overweight/en/ (accessed June 2017).

38. Jian Xin QI (1990) Determination of Cu, Zn, Fe, Ca, Mg, Na and $\mathrm{K}$ in serum flame by atomic absorption spectroscopy. Varian Instruments at Work issue AA-93, pp. 1-2. Palo Alto, CA: Varian, Inc.

39. $\mathrm{R}$ Development Core Team (2005) R: A Language and Environment for Statistical Computing. Vienna: R Foundation for Statistical Computing. 
40. European Food Safety Authority, Panel on Dietetic Products, Nutrition and Allergies (2010) Scientific Opinion on Dietary Reference Values for fats, including saturated fatty acids, polyunsaturated fatty acids, monounsaturated fatty acids, trans fatty acids and cholesterol. EFSA J 8, 1461.

41. Hotz C, Peerson JM \& Brown KH (2003) Suggested lower cutoffs of serum zinc concentrations for assessing zinc status: reanalysis of NHANES II (1976-1980). Am J Clin Nutr 78, 756-764

42. Jati I, Widmer C, Purwestri RC et al. (2014) Design and validation of a program to identify inadequate intake of iron, zinc, and vitamin A. Nutrition 30, 1310-1317.

43. Mandic Puljek M, Mandic ML, Perl A et al. (2005) Calcium intake, food sources and seasonal variations in Eastern Croatia. Coll Antropol 29, 503-507.

44. Lowe NM, Dykes FC, Skinner AL et al. (2013) Estimating zinc requirements for deriving recommendations. Dietary reference values for micronutrients: summary report from the EURRECA Network of Excellence. Crit Rev Food Sci Nutr 53, $1110-1123$.

45 Gurinović M, Kadvan A, Vukotić M et al. (2011) The quality of nutrition in schoolchildren and adult members of families. In Yugoslav Study of Atherosclerosis Precursors in Schoolchildren in Serbia: Twenty Years Follow-Up, pp. 343-368 [S Nedeljkovic, editor]. Belgrade: Medical Faculty, University of Belgrade.

46. Rodler I, Bíro L, Greiner E et al. (2005) Dietary survey in Hungary, 2003-2004. Orvosi Hetilap 146, 1781-1789.

47. Brants HAM, LoÈwik MRH, Westenbrink S et al. (1990) Adequacy of a vegetarian diet at old age (Dutch Nutrition Surveillance System). J Am Coll Nutr 9, 292-302.

48. Payette H \& Gray-Donald K (1991) Dietary intake and biochemical indices of nutritional status in an elderly population, with estimates of the precision of the 7-d food record. Am J Clin Nutr 54, 478-488.

49. Pennington JAT \& Schoen SA (1996) Total diet study: estimated dietary intakes of nutritional elements. Int $J$ Vitam Nutr Res 66, 350-362.

50. Galan P, Hercberg S, Soustre Y et al. (1985) Factors affecting iron stores in French females students. Hum Nutr Clin Nutr 39, 279-287.

51. Murphy SP (2002) Using the new dietary reference intakes to assess diets: a map to the maze. Nutr Rev 60 , $267-275$.

52. Nordic Council of Ministers (2012) Nordic Nutrition Recommendations 2012: Integrating Nutrition and Physical Activity, 5th ed. Nord 2014:002. Copenhagen: Nordic Council of Ministers.

53. Food and Agriculture Organization of the United Nations \& World Health Organization (2001) Human Vitamin and Mineral Requirements. Report of a Joint FAO/WHO Expert Consultation, Bangkok, Thailand. Rome: FAO Food and Nutrition Division.

54. Lauzon B, Volatier JL \& Martin A (2004) A Monte Carlo simulation to validate the EAR cutpoint method for assessing the prevalence of nutrient inadequacy at the population level. Public Health Nutr 7, 893-900.

55. Poslusna K, Ruprich J, de Vries JH et al. (2009) Misreporting of energy and micronutrient intake estimated by food records and $24 \mathrm{~h}$ recalls, control and adjustment methods in practice. Br J Nutr 101, Suppl. 2, S73-S85.

56. Sandstead HH (2000) Causes of iron and zinc deficiencies and their effects on brain. J Nutr 130, 2S Suppl., 347S-349S.

57. Kaganov B, Margherita C, Mazur A et al. (2015) Suboptimal micronutrient intake among children in Europe. Nutrients $\mathbf{7}$, 3524-3535.

58. Worthington-Roberts BS, Breskin MW \& Monsen ER (1998) Iron status of premenopausal women in a university community and its relationship to habitual dietary sources of protein. Am J Clin Nutr 47, 275-279.
59. Heath AL \& Fairweather-Tait SJ (2002) Clinical implications of changes in the modern diet: iron intake, absorption and status. Best Pract Res Clin Haematol 15, 225-241.

60. Brussaard JH, den Berg H, Hermus RJ et al. (1999) Approach of the US food and nutrition board to daily nutrient requirements: 'a useful basis for the European discussion on risk assessment of nutrients?' Report on a workshop organized by the European Academy of Nutritional Sciences (EANS) and TNO Food and Nutrition Research Institute, 11 December 1998, Brussels. Eur J Clin Nutr 53, 786-791.

61. Harvey LJ, Berti C, Casgrain A et al. (2013) EURRECAEstimating iron requirements for deriving dietary reference values. Crit Rev Food Sci Nutr 53, 1064-1076.

62. Cepeda-Lopez AC, Aeberli I \& Zimmermann MB (2010) Does obesity increase risk for iron deficiency? A review of the literature and the potential mechanisms. Int J Vitam Nutr Res 80, 263-270.

63. Lestienne I, Icard-Verniére C, Mouquet C et al. (2005) Effects of soaking whole cereal and legume seeds on iron, zinc and phytate contents. Food Chem 89, 421-442.

64. Koram K, Addae M, Ocran J et al. (2007) Population based reference intervals for common blood haematological and biochemical parameters in the Akuapem north district. Ghana Med J 41, 160-166.

65. Fakayode S, Owen SL, Pollard DA et al. (2013) Use of flame atomic absorption spectroscopy and multivariate analysis for the determination of trace elements in human scalp. Am J Anal Chem 4, 348-359.

66. Calenti JC, Sanchez A, Lorenzo-Lopez L et al. (2012) Laboratory values in a Spanish population of older adults: a comparison with reference values from younger adults. Maturitas 71, 396-401.

67. Dosoo DK, Kayan K, Adu-Gyasi D et al. (2012) Haematological and biochemical reference values for healthy adults in the middle belt of Ghana. PLoS One 7, e36308.

68. Sian L, Xiang MY, Miller LV et al. (1996) Zinc absorption and intestinal losses of endogenous zinc in young Chinese women with marginal zinc intakes. Am J Clin Nutr 63, 348-353.

69. Bailey AL, Maisey S, Southon S et al. (1997) Relationships between micronutrient intake and biochemical indicators of nutrient adequacy in a 'free-living' elderly UK population. BrJ Nutr 77, 225-242.

70. Skikne R \& Baynes RD (1994) Iron absorption. In Iron Metabolism in Health and Disease, pp 151-187 [JHJ Brock, JW Halliday, MJ Pippard et al., editors]. London: Saunders.

71. Heitmann BL, Milman N \& Hansen GL (1996) Relationship between dietary iron intake, corrected for diet reporting error, and serum ferritin in Danish women aged 35-65 years. Br J Nutr 75, 905-913.

72. Johnson PE, Hunt CD, Milne DB et al. (1993) Homeostatic control of zinc metabolism in men: zinc excretion and balance in men fed diets low in zinc. Am J Clin Nutr 57, 557-565.

73. Yokoi K, Sandstead HH, Egger NG et al. (2007) Association between zinc pool sizes and iron stores in premenopausal women without anaemia. Br J Nutr 98, 1214-1223.

74. Lim K, Booth A, Szymlek-Gay EA et al. (2015) Associations between dietary iron and zinc intakes, and between biochemical iron and zinc status in women. Nutrients $\mathbf{7}$, 2983-2999.

75. Kelkitli E, Ozturk N, Aslan NA et al. (2016) Serum zinc levels in patients with iron deficiency anemia and its association with symptoms of iron deficiency anemia. Ann Hematol 95, 751-756.

76. Darmon N \& Drewnowski A (2008) Does social class predict diet quality? Am J Clin Nutr 87, 1107-1117.

77. Aggarwal A, Monsivais P, Cook AJ et al. (2011) Does diet cost mediate the relation between socioeconomic position and diet quality? Eur J Clin Nutr 65, 1059-1066. 
78. Giskes K, Avendano M, Brug J et al. (2010) A systematic review of studies on socioeconomic inequalities in dietary intakes associated with weight gain and overweight/ obesity conducted among European adults. Obes Rev 11, 413-429.

79. Arnaud J, Touvier M, Galan P et al. (2010) Determinants of serum zinc concentrations in a population of French middle-age subjects (SU.VI.MAX cohort). Eur J Clin Nutr 64, 64, 1057-1064.

80. Friel S, Kelleher CC, Nolan G et al. (2003) Social diversity of Irish adults' nutritional intake. Eur J Clin Nutr 57, 865-875.

81. Van Rossum CT, Van de Mheen H \& Witteman JC (2000) Education and nutrient intake in Dutch elderly people. The Rotterdam Study. Eur J Clin Nutr 54, 159-165.

82. Hulshof KF, Brussaard JH, Kruizinga AG et al. (2003) Socioeconomic status, dietary intake and $10 \mathrm{y}$ trends: the Dutch National Food Consumption Survey. Eur J Clin Nutr 57, 128-137.

83. Roos E, Prattala R, Lahelma E et al. (1996) Modern and healthy?: socioeconomic differences in the quality of diet. Eur J Clin Nutr 50, 753-760.

84. Hotz C (2007) Dietary indicators for assessing the adequacy of population zinc intakes. Food Nutr Bull 28, 3 Suppl., S430-S453.

85. Wood RJ (2000) Assessment of marginal zinc status in humans. J Nutr 130, 5 S Suppl, 1350S-1354S.
86. Wada L, Turnlund JR \& King JC (1985) Zinc utilization in young men fed adequate and low zinc intakes. J Nutr $\mathbf{1 1 5}$, $1345-1354$.

87. Lowe NM, Fekete K \& Decsi T (2009) Methods of assessment of zinc status in humans: a systematic review. Am J Clin Nutr 89, issue 6, 2040S-2051S.

88. Reed S, Qin X, Ran-Ressler R et al. (2014) Dietary zinc deficiency affects blood linoleic acid:dihomo- $\gamma$-linolenic acid (LA:DGLA) ratio; a sensitive physiological marker of zinc status in vivo (Gallus gallus). Nutrients $\mathbf{6}$, $1164-1180$.

89. Knez M, Stangoulis JCR, Zec M et al. (2016) An initial evaluation of newly proposed biomarker of zinc status in humans - linoleic acid:dihomo- $\gamma$-linolenic acid (LA:DGLA) ratio. Clin Nutr 15, 85-92.

90. James PT (2004) Obesity: the worldwide epidemic. Clin Dermatol 22, 276-280.

91. Suskind DL (2009) Nutritional deficiencies during normal growth. Pediatr Clin North Am 56, 1035-1053.

92. Brown KH, Rivera JA, Bhutta Z et al. (2004) International Zinc Nutrition Consultative Group (IZiNCG) technical document \#1. Assessment of the risk of zinc deficiency in populations and options for its control. Food Nutr Bull 25, 1 Suppl. 2, S99-S203. 